\title{
Design and Fabrication of Waste Oil Fired Furnace
}

\author{
Navaneeth Kashyap K V, Yashas M S, Yogesh Kumar K J
}

\begin{abstract}
The study carried out a design and fabrication of an waste oil-fired furnace. The study focused on ensuring a high efficiency in melting of aluminium, by effectively minimizing heat losses, and maximizing heat generation. To achieve this, a composite refractory material consisting of cement, asbestos, and clay was used, and waste oil was splashed which is used as fuel with the help of blower which is running at $3000 \mathrm{rpm}$ and power rating of $1 \mathrm{hp}$. The working pressure of furnace is $5.86 \times 105 \mathrm{~N} / \mathrm{m} 2$. Changes in the furnace geometry were negligible indicating a long service life potential. With a useful heat input, the furnace is able to melt aluminium at a pouring temperature of $6600 \mathrm{C}$. The design is considered safe since the working pressure does not exceed the working stress of its casing which is made of mild steel.
\end{abstract}

Keywords : Oil-Fired Furnace, Refractory,Crucible, Furnace, Refractory,Combustion.

\section{INTRODUCTION}

$\mathrm{B}$ lacksmith is an earliest and known trade to humans.

With the increase in the use of metals because of their outstanding mechanical properties, foundry operation keeps increasing. Aluminium is one of the most recycled metal in the world. Aluminium recycling is one of the most profitable business around the globe. This could be attributed to the fact that it takes less amount of energy to produce aluminium through recycling than through its ore. Therefore, it is necessary to tackle every available source of energy to ensure that the field of aluminium recycling obtain more attention. In trying to achieve this task, the use of furnaces cannot be over emphasized. A furnace is a lagged enclosure designed basically for heating of metals in order to obtain required output.. It is to end that this study intends to design and construct an waste oil-fired furnace with the main objective of ensuring high efficiency in melting of aluminium, by effectively minimizing heat losses, and maximizing heat generation.

Revised Manuscript Received on December 30, 2019.

* Correspondence Author

Navaneeth Kashyap K V, Department of Mechanical Engineering, Maharaja Institute of Technology Mysore, Mandya, Karnataka 571438. Email: nkv006@gmail.com

Yashas M S, Department of Mechanical Engineering, Maharaja Institute of Technology Mysore, Mandya, Karnataka 571438. Email: yashasgowda177@gmail.com

Yogesh Kumar K J, Department of Mechanical Engineering, Maharaja Institute of Technology Mysore, Mandya, Karnataka 571438. Email:yogesh_nie21@yahoo.com

(C) The Authors. Published by Blue Eyes Intelligence Engineering and Sciences Publication (BEIESP). This is an open access article under the CC BY-NC-ND license (http://creativecommons.org/licenses/by-nc-nd/4.0/)

\section{Classification of Melting furnaces:}

I. Fuel Fired Furnace

a. Gas Fired Furnace

b . Oil Fired Furnace

c. Coke Fired Furnace

d. Air Fired Furnace [Reverberatory Furnace]

II. Electrical Furnace

a. Electrical resistance furnace

b.Electrical induction furnace

i.Low frequency

ii. High frequency

c. Arc Furnace

i. Direct arc electric furnace

ii. Indirect arc electric furnace

\section{LITERATURE REVIEW}

Through the comprehensive review of literature, the basic operations of oil fired furnace and importance of its individual terms are studied. Through the literature we have known that the cost of oil fired furnaces is less than induction furnace. So there exists the opportunities for improving the efficiency of metal melting processes by using the firing process. The oil fired furnace should be designed, optimize and install carefully in order to maximize the rate of production and minimize cost of production.

\section{A. PROBLEM DEFINITION}

From the literature survey it is seen that use of oil fired furnaces exits from long back, but less work is carried out using waste engine oil for firing the furnace. Hence in the present research work an attempt is made to design, fabricate and test the furnace fired with waste engine oil.

\section{B. OBJECTIVES}

The aims and objectives of the present study are as follows:

- To design economical oil fired furnace with better performance.

- Fabrication of oil fired furnace based on design.

- To test the furnace .

\section{METHODOLOGY}

Following are the Methodologies adopted to attain the above stated objectives

- To study the existing types of furnaces.

- Design the individual components of furnace.

- Selection of suitable materials for fabrication.

- Fabrication of oil fired furnace.

- Testing the fabricated furnace by melting aluminium. 


\section{Design and Fabrication of Waste Oil Fired Furnace}

\section{CONCEPTUAL DESIGN:}

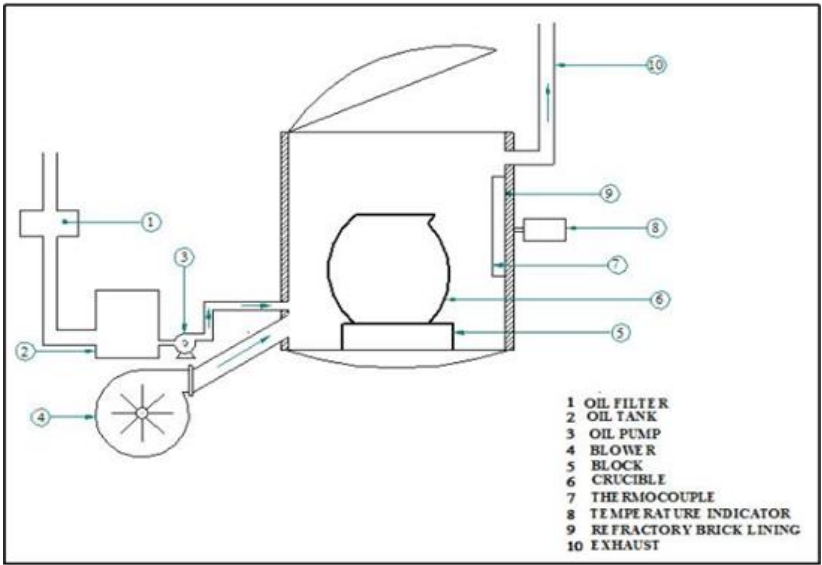

Fig. 1. Conceptual of furnace design setup

\section{A. Construction:}

- Furnace consist of outer steel lined with a refractory lining, the refractory wall resist heat shock and heat loss. crucible is supported as shown. At the bottom of the shell, a small opening is made through which fuel [oil+air] is passed and for complete combustion air is forced into the furnace by means of a small blower.

- At the top of the furnace, a small opening is made for escaping of hot gas is provided.

\section{B. Working principle:}

In operation crucible is charged with metal or its alloys and lid is closed. The fuel [oil+air] mixture is introduced into the furnace and it is ignited which cause flame, rises from bottom of the furnace, swirls around the crucible and crucible starts heating up. After the metal melts and reaches the desired temperature, the fuel is cut-off and lid is opened, crucible is taken from the furnace with the help of tongs. The slag floating on the surface of melt is removed and molten metal is poured into the mould cavity.

\section{Selection of Materials}

\section{Casing:}

Function:Houses the refractory, pot and combustion chamber.

Material used: Mild steel

Reason: Strength

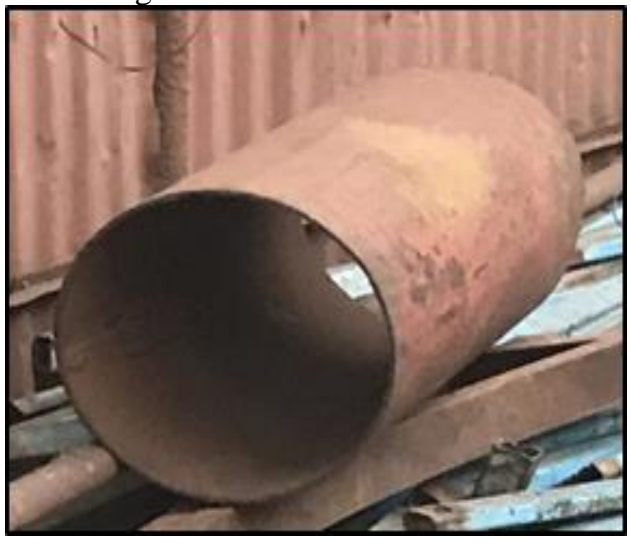

Fig. 2. Casing
- At the bottom, a round block/base is placed upon which a

\section{Crucible pot}

Function: Contains aluminum to be melted.

Material used: Graphite.

Reason: High thermal conductivity.

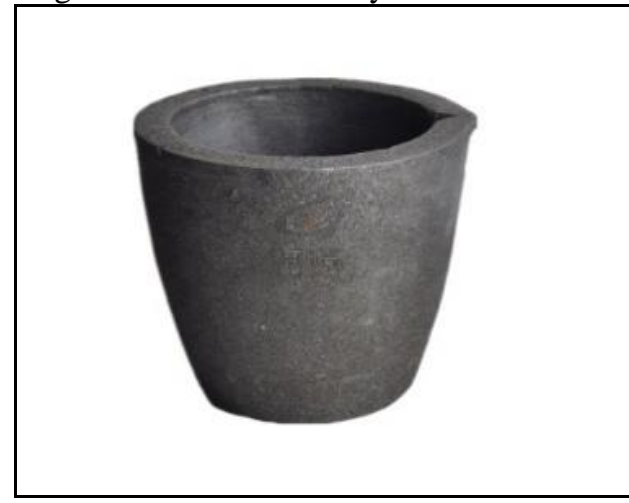

Fig. 3. Crucible

\section{Refractory Wall}

Function: Prevents heat loss due to conduction, retains heat within the combustion chamber and maintains high temperature needed for complete fuel combustion.

Material used: Portland cement, Asbestos, Clay.

Reason:Poor thermal conductivity and high temperature resistant.

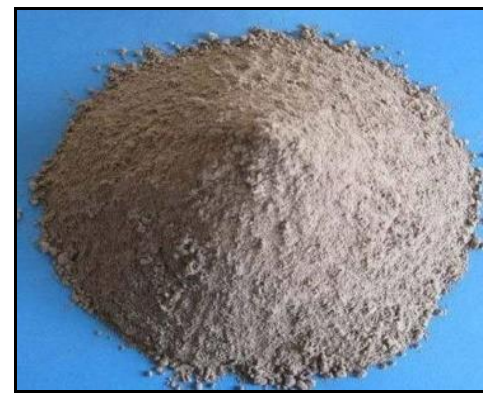

Fig. 4. Refractory mixture

\section{Fuel delivery hoses}

Function: Delivers fuel to the furnace Material used: 3/8" inch hose

Reason: Flexibility, corrosion resistant

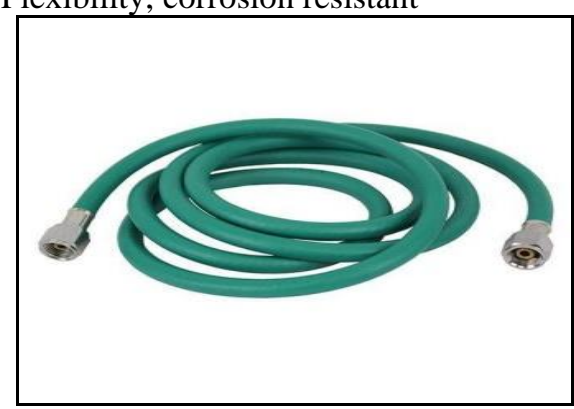

Fig. 5. Hose

Fuel Tank:

Function: Stores the fuel

Material used: Plastic/Aluminum

Reason: Corrosion resistant and supports long term storage of fuel. 


\section{Blower:}

Function: Produce high pressured air to energize the fuel.

Material used/Type: Electric blower

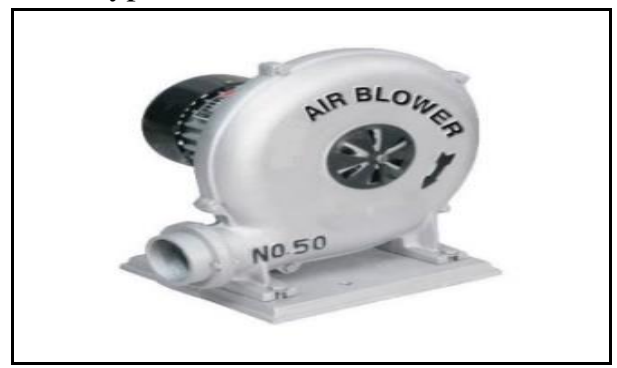

Fig. 6. Blower

\section{DESIGN CALCULATION:}

\section{Notations:}

$>\mathbf{T}$ - Design temperature $\left(\right.$ in $\left.{ }^{\circ} \mathrm{C}\right)=800^{\circ} \mathrm{C}$

$>\mathbf{d}$ - external diameter of the furnace (from table) (in $\mathrm{mm})=$ $400 \mathrm{~mm}$

$>$ C - corrosion allowance $=0.75 \mathrm{~mm}$

$>\mathbf{e}$ - thickness the furnace $=5 \mathrm{~mm}$

$>\mathbf{L}$ - length of the furnace $=600 \mathrm{~mm}$

$>\mathbf{P}$ - design pressure (in $\mathrm{kg} / \mathrm{cm}^{2}$ )

$>\mathbf{E}_{\mathbf{t}}-$ Specified minimum elevated temperature yield stress $=1872 \mathrm{~N} / \mathrm{mm}^{2}$

$>\mathrm{S}_{1}$ - Safety factor (for note 1$)=2.5$

$>\mathbf{U}$ - percentage out of roundness to be taken as 1.5 for plain furnaces

$\boldsymbol{\sigma}$ - allowable stress of the material (mild steel) $=247 \times 10^{6}$ $\mathrm{N} / \mathrm{m}^{2}$

\section{Calculation:}

\section{Working Pressure, $\mathrm{P}$ :}

$$
P=\frac{2 E_{t}(e-C)}{\left(S_{1} \times d\right)} \times \frac{(1+(d / 15 L))}{(1+\underline{0.03 d u})}
$$

$$
=\frac{2 \times 1872 \times(5.0 .75)}{(3 \times 400)} \times \frac{(1+400 /(15 \times 600))}{1+\frac{(0.03 \times 400 \times 1.5)}{(5-0.75) \times(1+(400 /(0.3 \times 600))}}
$$$$
=(13.26 \times 0.4512)
$$

$$
P=5.98 \mathrm{~kg} / \mathrm{cm}^{2}=5.86 \times 10^{5} \mathrm{~N} / \mathrm{m}^{2}
$$

\section{Volume of furnace, $\mathrm{V}$ :}

$$
\begin{aligned}
V & =\text { Area } \times \text { Length } \\
& =\frac{\pi \times d^{2} \times \mathrm{L}}{4} \\
& =\frac{\pi \times\left(400^{2}-390^{2}\right)}{4} \times 600 \\
& =3.72 \times 10^{6} \mathrm{~mm}^{3}=3.72 \text { litres }
\end{aligned}
$$

\section{Determination of the minimum thickness of the furnace walls:}

$$
\begin{aligned}
&>\mathrm{t}= \frac{\mathrm{P} * \mathrm{~d}}{2 \sigma j-\mathrm{P}}+\mathrm{C} \\
& \mathrm{t}= \frac{5.86 \times 10^{5} \times 400 \times 10^{-3}}{\left.2 \times 247 \times 10^{5} \times 0.70\right)-\left(5.86 \times 10^{5}\right)}+(0.75 \times 10-3) \\
& \mathrm{t}=1.428 \times 10^{-3} \mathrm{~m}=1.428 \mathrm{~mm}
\end{aligned}
$$

Therefore the minimum thickness of the furnace wall was found to be $1.428 \mathrm{~mm}$. But we have chosen thickness of furnace wall as $5 \mathbf{m m}$

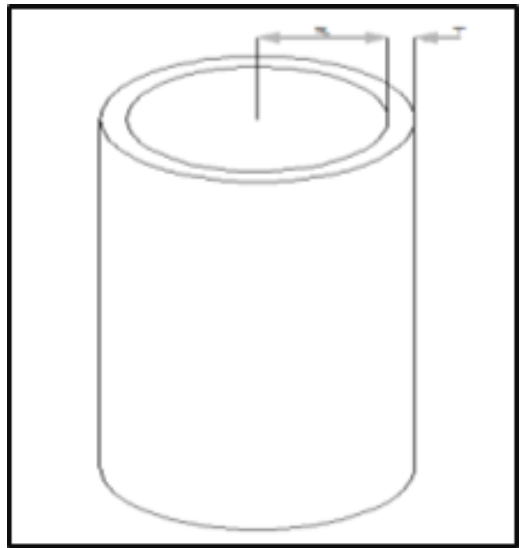

4. Change in length of furnace due to internal pressure:

$$
\Delta \mathrm{L}=\frac{\mathrm{Pd}}{4 \mathrm{EE}}(1-2 \mathrm{v}) \times \mathrm{L}
$$

$\Delta L=\underline{5.86 \times 10^{5} \times 400 \times 10^{-3}} \times\left(1-(2 \times 3) \times 600 \times 10^{-3}\right)$ $4 \times 5 \times 10^{3} \times 206 \times 10^{9}$

$\mathrm{LL}=0.0136 \mathrm{~mm}$

5. Change in diameter of furnace due to internal pressure:

$$
\Delta \mathrm{d}=\frac{\mathrm{Pd}}{4 \mathrm{E}}^{(2-v)}
$$

$\Delta d=\underline{5.86 \times 10^{5} \times\left(400 \times 10^{-3}\right)^{2}} \times(2-.3)$

$$
4 \times 5 \times 10^{-3} \times 206 \times 10^{9}
$$

$\Delta d=0.00386 \mathrm{~mm}$

\section{A. 2D Drawing of the furnace}

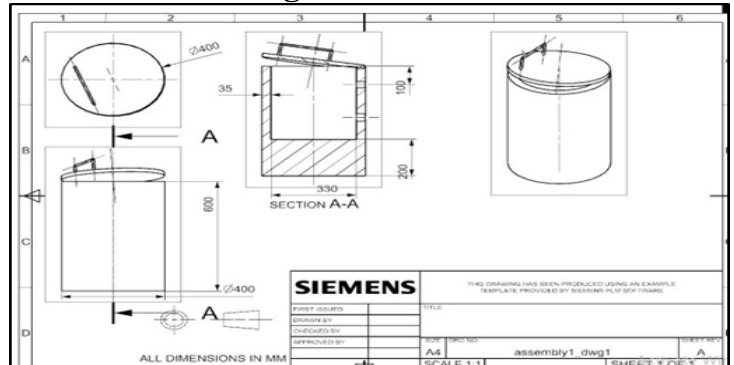

Fig.7.Furnace-1 [Main furnace] 


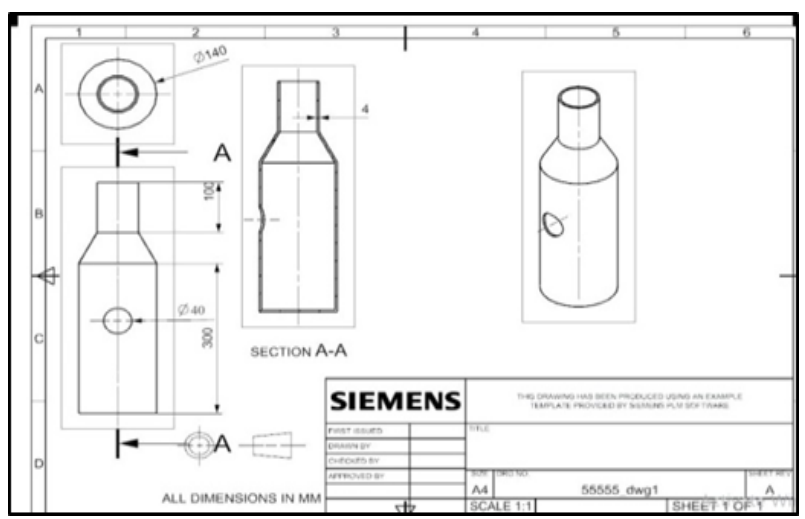

Fig. 8. Furnace-2

\section{EXPERIMENTATION}

Initial Furnace-2 is loaded with Charcoal, wooden pieces and a few drops of Petrol is been added (charged) inside the furnace and ignited with matchstick and is connected to Main Furnace. And all the connections like fuel tank pipe and blower pipe is connected and blower is turned ON. Slowly the fuel tank valve is opened and the waste oil gets into the furnace chamber. An effective flame was been produced as shown in figure.
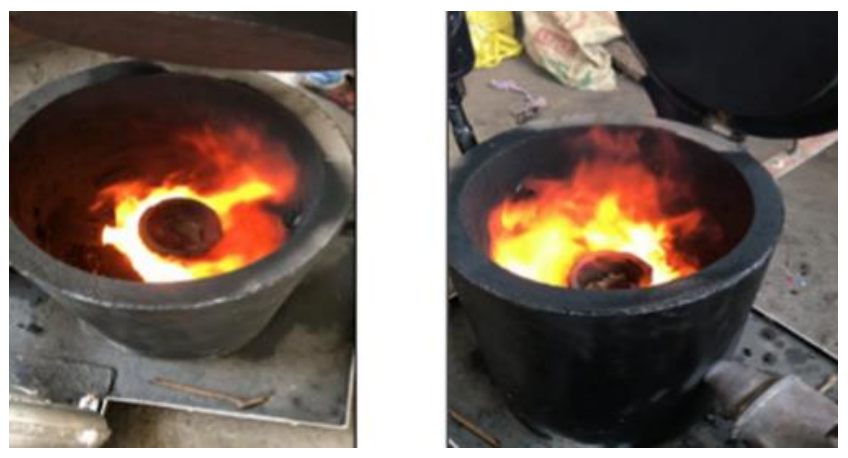

Fig. 9. Flame produced inside the furnace

Table 1: Furnace time-temperature result

\begin{tabular}{|l|l|l|}
\hline Time (min) & $\begin{array}{l}\text { Temperature } \\
\text { attained }\left({ }^{\circ} \mathrm{C}\right)\end{array}$ & $\begin{array}{l}\text { Heating Rate } \\
\left({ }^{\circ} \mathrm{C} / \mathrm{min}\right)\end{array}$ \\
\hline 3 & 130 & 43.33 \\
\hline 6 & 265 & 44.16 \\
\hline 9 & 410 & 45.55 \\
\hline 12 & 530 & 44.16 \\
\hline 15 & 660 & 44 \\
\hline 18 & 780 & 43.33 \\
\hline & Average & 44.09 \\
\hline
\end{tabular}

Crucible is placed inside the furnace chamber and the waste aluminium like chips of aluminium, plates, and wires are kept inside the furnace and the flames is passed into the furnace chamber. The developed furnace successfully melts the aluminium within 30mins into molten state. The residues and slag is removed carefully. This molten aluminum is poured into the mould with care to form billets of aluminium bars. Molds were also prepared.

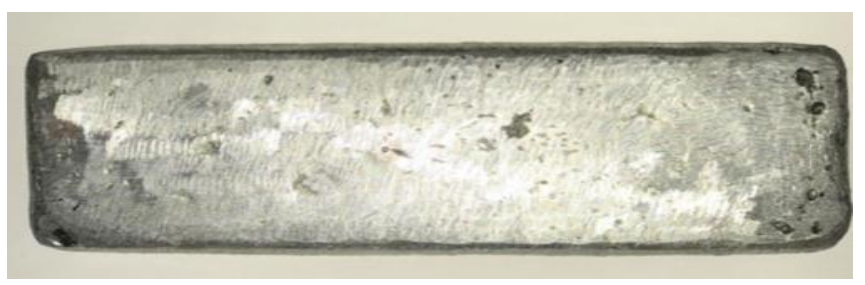

Fig. 10. Flat Specimen $50 \mathrm{~mm}$ width, $15 \mathrm{~mm}$ thick and $185 \mathrm{~mm}$ length

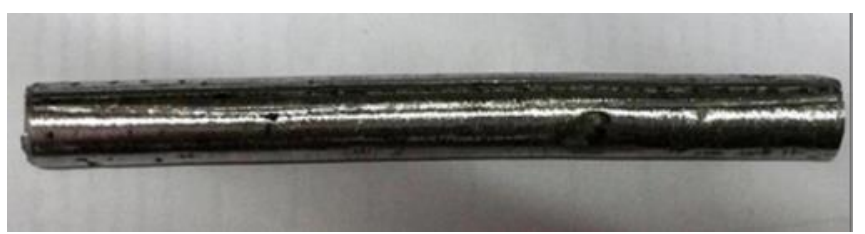

Fig. 11. Circular Specimen 15mm Diameter,150mm length

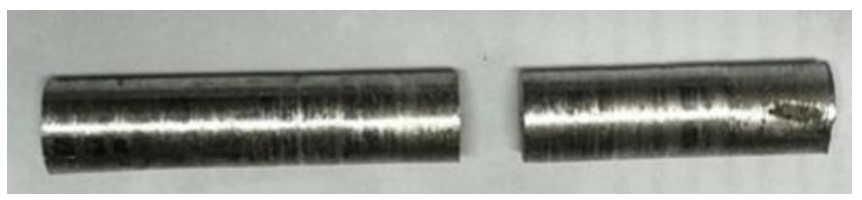

Fig. 12. Circular Specimen $18 \mathrm{~mm}$ Diameter, 100mm length \& $50 \mathrm{~mm}$ length

The above specimens are developed using the waste aluminium like chips, scrap collected from machine shops, cable wires etc. the details of slag and residue collected after melting is tabulated below.

Table 2 - Detailed table of specimen melted

\begin{tabular}{|c|l|c|c|}
\hline $\begin{array}{c}\text { Sl. } \\
\text { No. }\end{array}$ & \multicolumn{1}{|c|}{ Type of Scrap } & $\begin{array}{c}\text { Slag } \\
\text { collected } \\
\text { (in Grams) }\end{array}$ & $\begin{array}{c}\text { Pure } \\
\text { Aluminium } \\
\text { Extracted (in } \\
\text { Grams) }\end{array}$ \\
\hline 1 & $\begin{array}{l}\text { WastePlates or } \\
\text { scrap aluminium } \\
\text { sheets-500 }\end{array}$ & 150 & 350 \\
\hline 2 & $\begin{array}{l}\text { Cables and } \\
\text { chips-400 and }\end{array}$ & 120 & 343 \\
\hline 3 & $\begin{array}{l}\text { Plates } \\
\text { panels-500 }\end{array}$ & 340 \\
\hline
\end{tabular}

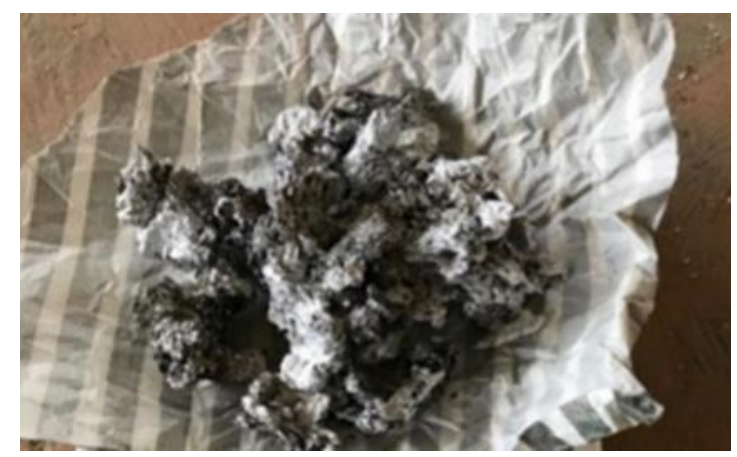

Fig. 13. Slag Collected after melting Plates and Panels

\section{A. Material Hardness Test:}

After the pure aluminium was extracted from scrap aluminium.

\section{Published By:}

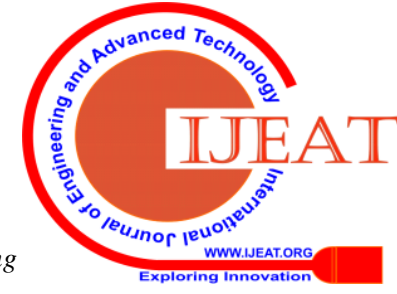


Rockwell hardness was conducted to known the hardness number of aluminium which was melted and moulded in the furnace

Material type 1: Here the waste aluminium sheets were melted and moulded.
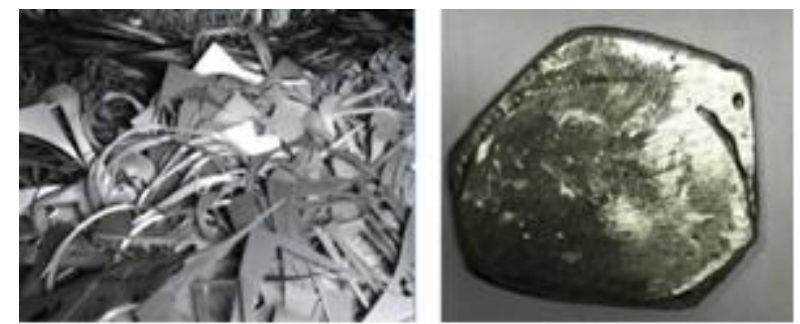

Fig 14: a) Scrap aluminum sheet b) Moulded aluminum

For the developed material Rockwell hardness test is conducted to check the hardness number of the material developed and compared with the hardness number of pure aluminium standard values. The average Rockwell hardness number of the specimens developed (Material-1, Materila-2 and material-3) were very close to the standard hardness number of aluminium that is 27-32. Hence the furnace developed is capable of extracting pure metal from the scrap. If care is taken while removing the slag and residues the quality of material may be increased.

Table 3: Tabulation of Rockwell hardness test trials

\begin{tabular}{|c|c|c|c|c|c|}
\hline $\begin{array}{c}\text { Sl. } \\
\text { No }\end{array}$ & Specimen & Trail-1 & Trail-2 & Trail-3 & $\begin{array}{c}\text { Average } \\
\text { Rockwell } \\
\text { hardness } \\
\text { Number }\end{array}$ \\
\hline 1 & Material-1 & 24 & 27 & 25 & 25.33 \\
\hline 2 & Material-2 & 28 & 27 & 28 & 27.66 \\
\hline 3 & Material-3 & 26 & 25 & 23 & 24.66 \\
\hline
\end{tabular}
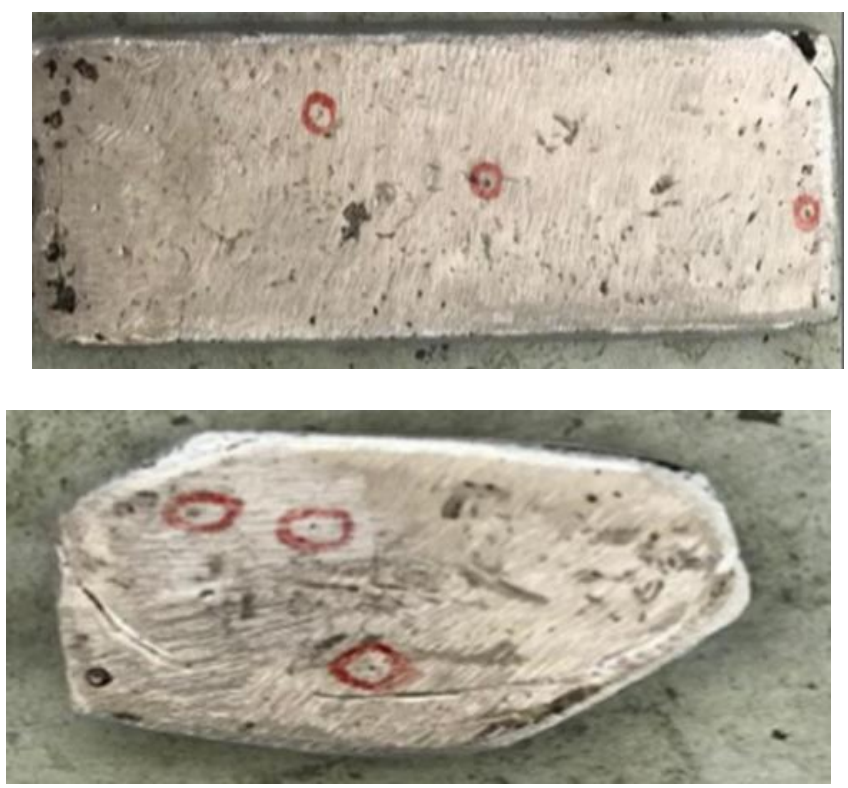

Material type 2: Here waste aluminium frames along with aluminium wires was melted and converted into bar.
Fig. 15. Indentions from test

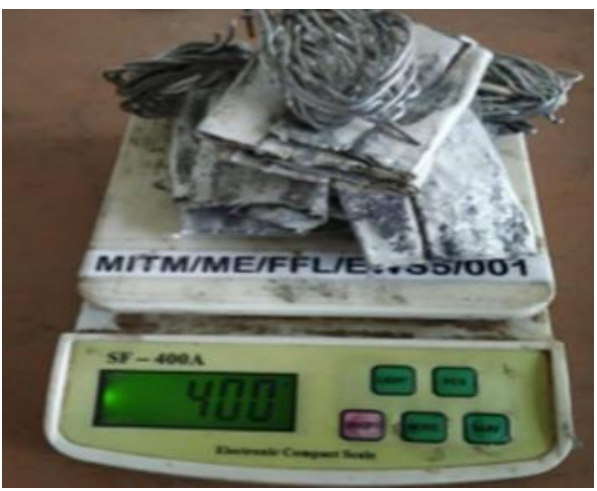

Fig. 16. Weight of scrap material

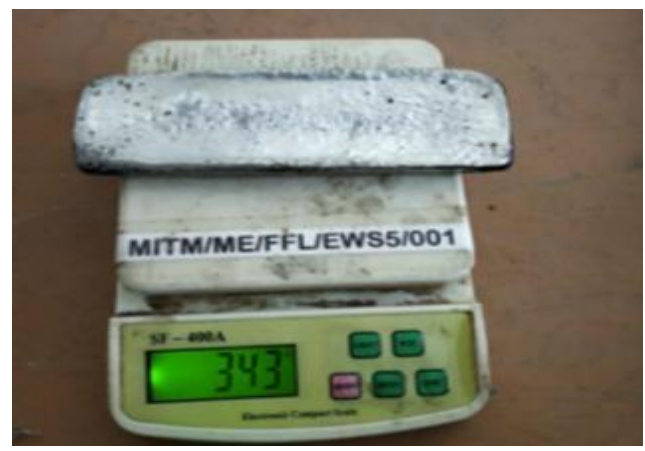

Fig. 17. Weight of aluminum bar

\section{RESULT AND DISCUSSION}

\begin{tabular}{|c|c|}
\multicolumn{2}{|c}{ Table $\mathbf{4}$ - Results } \\
\begin{tabular}{|c|c|}
\hline Parameter & Values \\
\hline Working Pressure & $5.86 \times 10^{5} \mathrm{~N} / \mathrm{m}^{2}$ \\
\hline Volume of furnace & $3.72 \times 10^{6} \mathrm{~mm}^{3}$ \\
\hline $\begin{array}{c}\text { The minimum thickness of } \\
\text { the furnace walls }\end{array}$ & $1.428 \mathrm{~mm}$ \\
\hline $\begin{array}{c}\text { Change in length of furnace } \\
\text { due to internal pressure }\end{array}$ & $0.0136 \mathrm{~mm}$ \\
\hline $\begin{array}{c}\text { Change in diameter of furnace } \\
\text { due to internal pressure }\end{array}$ & $0.00386 \mathrm{~mm}$ \\
\hline Average Heat Rate & $44.09{ }^{\circ} \mathrm{C} / \mathrm{min}$ \\
\hline
\end{tabular}
\end{tabular}

From the results it is seen that the working pressure within the combustion chamber is more than the atmospheric pressure $\left(1 \times 10^{5} \mathrm{~N} / \mathrm{m} 2\right)$, and as a result it would exert pressure on the wall of the refectory. The stress and working pressure sets up in the wall is counteracted by the compressive stress exerted on the wall by the crucible casing. Hence, with the tangential (tensile) and radial (compressive) stresses being equal, an equilibrium is attained. Also, the design is considered to be safe since the value of the working stress of steel which is approximately $200 \mathrm{Mpa}$ is greater than the working pressure. This implies that the thickness of the furnace will withstand failure.

\section{CONCLUSION}

Therefore, Based on the results obtained from the performance test carried out on the fabricated crucible furnace the set objectives was achieved,

Published By:

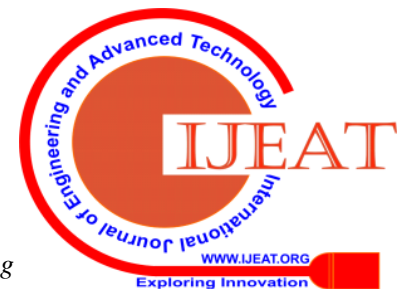


such as fuel economy, time required for the operation, the following conclusions can also be made:

1. The crucible furnace proved to be effective for melting of aluminum.

2. Melting aluminum in the crucible furnace proved to be more economical and time saving during operation.

3. It can be concluded that the device is suitable for use in small scale foundries

4. The fabricated crucible furnace reached a temperature of 750 oC at 20 mins.

\section{REFERENCES}

1. M. S. Liu ,C. K. Choi and C. W. Leung, "Start-up Analysis of Oil- Fired Furnace - The Smoothing Monte Carlo Model Approach", Heat and Mass Transfer 37 (2001) Springer- Verlag 2001 , Pages 449-457.

2. Chukwudi. B.C. and M.B. Ogunedo. 2017. Design and Development of a Gas Fired Reverberatory Furnace: In View of Huge Gas Reserves in Nigeria. Pacific Journal of Science and Technology.

3. Chun Lou a, Wen-Hao Li a, Huai-Chun Zhou a, Carlos T. Salinas, "Experimental Investigation on Simultaneous Measurement of Temperature Distributions and Radiative Properties in an Oil Fired Tunnel Furnace by Radiation Analysis", International Journal of Heat and Mass Transfer 54 (2011), Pages 1-8.

4. Osarenmwinda J. O., (2015). Fabrication and Performance Evaluation of Oil-Fired Crucible Furnace using locally sourced materials. International Journal of Engineering Research and Applications. Vol. 5, Pg 29-33.

5. www.productivity.in./Types_and Classification_of_Different_Furnace.

6. "Dr. S.V. GUPTA" book on "A TREATISE ON INDIAN BOILER REGULATIONS".

\section{AUTHORS PROFILE}

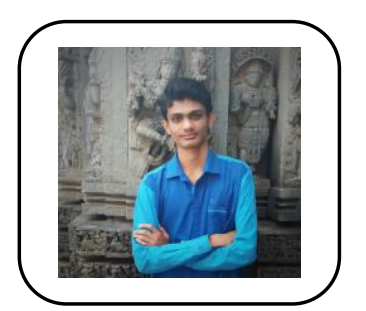

Navaneeth Kashyap K V, Mechanical Engineer,studied at department of Mechanical Engineering, Maharaja Institute of Technology Mysore, Mandya,Karnataka 571438.

Email:nkv006@gmail.com

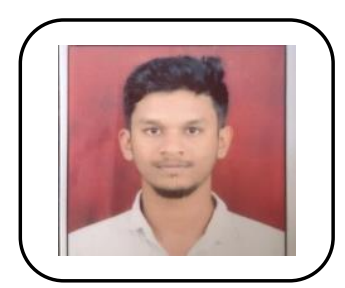

Yashas M S, Mechanical Engineer, studied at department of Mechanical Engineering, Maharaja Institute of Technology Mysore, Mandya,Karnataka 571438.

Email: yashasgowda177@gmail.com

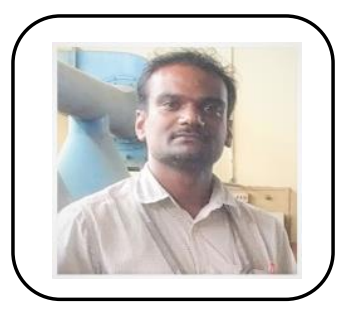

Yogesh Kumar K J, Assistant Professor, Department of Mechanical Engineering, Maharaja Institute of Technology Mysore, Mandya,Karnataka 571438.

Email:yogesh_nie21@yahoo.com 